International Journal of Language Education and Culture Review, Vol.2 (2) December 2016, 60 - 70. $\vdots_{. . .}^{\bullet}:$ IJLECR Available online at http://journal.unj.ac.id/unj/index.php/ijlecr

DOI:doi.org/10.21009/IJLECR.022.08

\title{
POLYTECHNIC STUDENTS' PREFERENCES IN CHOOSING THE READING MATERIALS FOR ENGLISH LANGUAGE CLASSROOM
}

\author{
Santhy Subbarau', Marissa Bt. Abd. Mustafa² \\ Department of General Studies Department, \\ Polytechnic Banting SelangorUniversiti Kebangsaan Malaysia \\ santhy.e@email.com ${ }^{1}$ \\ fifimarissa@gmail.com²
}

\begin{abstract}
Reading has been a core of language learning skills and an essential tool for lifelong learning for centuries. Malaysian's language classroom scenario looks upon reading as a toughest task amongst the students in comprehending English texts. Facts were found referring to reading and the selection of materials correlates in bringing the best in comprehending what has been read. In Polytechnic System, language learning in diploma courses is compulsory. In an absolute condition, it's to highlight on the selection of reading materials on what do students seek and preferred. Students want variety and look into many modes for aspiration as a guide and input for the language learning classroom. This study aims to identify the polytechnic students' preferences towards reading materials and to find out the factors that influence the polytechnic students' choice of reading materials. Samples of respondents are from Polytechnic Banting Selangor (PBS), the diploma students in Mechanical and Aircraft Maintenance Engineering department.
\end{abstract}

Keywords: Reading selection, Reading materials and Reading choices

Reading is known as one of the most important aspects of any language and it becomes an essential tool for lifelong learning for learners (Noorizah, 2011). However it appears that Malaysian students largely are facing the problem of comprehending English texts. These can be seen in the poor performance of the students reading comprehension examinations (Nair,2003). There are many factors that may contribute to the less encouraging performance in students reading comprehension, one of the most important factors is identified as material selection. Students will have difficulties learning English as a second language without appropriate learning materials in the classroom. Over the years linguist/researcher/educators have been debating in order to decide the most appropriate reading materials to use in reading comprehension. A significant amount of research shows that there is something about the type of reading text that should be looked into and analyzed carefully.

Selecting reading materials for students especially in English language classroom could be very challenging for teachers/educators as according to Aries (2007) since many criterion need to be taken into account in the selection process including students' interests. Aries also pointed out that no matter how difficult or easy the text might be, it will still be problematic for students if it it's not tackling their interest. Hence, the first step of selecting material for students is that; choose a text that that is based on students' interest as what stated by Anderson (1982), children paid more attention to interesting than non-interesting materials. The materials which are selected on the basis of students' preferences will actively encourage students' participation in reading comprehension and subsequently will improve their reading comprehension performance. Thus, clearly there is a need for this study to be conducted as to identify the students' preferences towards reading materials which the results will be beneficial for teachers/educators in making decision in selecting appropriate materials for students.

The study is done in a polytechnic, at Banting Polytechnic, which is an educational institution with 
$100 \%$ enrolment of domestic students from all over Malaysia. The study is conducted through survey methodology where questionnaires were distributed in the language classrooms. The respondents were the students at Banting Polytechnic who enrolled for the diploma programmes which are from Diploma in Mechanical Engineering and Diploma in Aircraft Maintenance Engineering. The questionnaire is designed to fit the students who are studying in polytechnic. The age range of these students is 19 years old to 22 years old. Due to the norms of enrolment, which is the number of male students enrolling compared to female students is more every semester; our respondents too also show that the male students outnumbered the female students. The male were 22 students and female were only 4 of them. Nevertheless, our study is to find out on the students' preferences in choosing the reading materials for English Language classroom on all students not gendered based. They come from multiple races found in Malaysia who are Malay, Chinese, Indian, Bidayuh and of speaking multiple first languages on their daily usage of language

1) To identify the polytechnic students' preferences towards reading materials

2) To find out the factors that influence the polytechnic students' choice of reading materials

The study revolves around these questions:

1) What are the students' preferences towards choosing reading materials?

2) Why the students choose that materials and what influence them to do the selection?

Since the study revolves on the preferences shown by the students on their choice of reading materials, it is also brought to attention on how external factors can influence them as well guide them to make a fruitful choice in selecting reading materials. It is also to unveil the choices they were making on the reading materials so far as well as where they could have found an avenue to look for more reading materials. The reading material which they have selected somehow or rather as a serious impact on their work in their language classroom as well as able to see the differences in choosing the relevant reading materials at most times. Some even left baffled on not knowing authors names and as well as not remembering the names of the books read. The questionnaire guided them on many issues such as favourite genres of the materials looked for, factors influencing them in their reading material selections, sources they look for most of times, and how the teachers/educators can bring aid to bringing their reading interest to greater heights. The study will be beneficial for all diploma level students in higher institutions on reading selection found in wide variety of avenues or sources and how the educators can project reading to them in the most appropriate atmosphere rather than bringing hostility in general towards reading.

In bringing out the results, we had few limitations where the number of samples or respondents of where having the inability to answer the research questions. Due to their poor reading interest and never had much interest in reading L2 materials or text the respondents show limitation in answering the questions. In general, the limitations had an impact on the quality of our findings and the ability for us to answer our research questions and/or hypotheses. As it is understood student learn the language as a subject every other semester and probably seen not a major requirement to read materials/books in language. The curriculum requires every subject to be thought in English Language but being L2, the respondent or the student of this polytechnic do not find it as a great need to improvise or rushed adrenalin to find for texts in language. It is a simple understanding that such limitation deters the research to be conducted well and nevertheless the researchers would want to take into consideration the higher ability students in future research which can somewhat give a better result in knowing the students' preferences in choosing the reading materials for English language classroom.

In this research many at times we found students were not doing any in depth reading but in many ways it showed tremendous variety in selection of reading material. Nevertheless, the respondents did show variety in books or reading materials which they were fond of were in wide range of genres. It is found from the principle of freedom of choice from Ray Williams's (1986), the third principle out of the top ten principles that learners choose what they want to read. Learners can select texts as they do in their own language by choosing texts they expect to understand, to enjoy or to learn from. Correlative to this principle, learners are also free, indeed encouraged, to stop reading anything they find to be too difficult, or that turns 
out not to be of interest. In another finding, what Henry noticed about her L1 non-reading undergraduates is no less true in foreign language reading: "my students needed to read for themselves, not for me" (1995: 6). For students used to working with textbooks and teacher-selected texts, the freedom to choose reading material (and freedom to stop reading) may be a crucial step in experiencing foreign language reading as something personal.

It is well said by Henry, although there may be a class or homework assignment, extensive reading puts the student in charge in other important ways. As Henry observes, "compliance means reading books, but other than that, the purposes and pleasures to which students put their reading are entirely their own" (p. 69). This encourages students to become responsible for their own learning. Samuels, in discussing first language reading, claims that "unless we phase out the teacher and phase in the learner, many of our students will fail to become independent because throughout their education they were always placed in a dependent role -- dependent on the teacher" (1991:17).

There are a number of studies that have been conducted which related to the present study. Nomakhosazana (2002) have conducted a study, looking into the Grade 11 ESL students' reading preferences. The study also has elicited some other important aspects for instance, role played by people in their surrounding as well as the environment in promoting a love for reading. The findings show that learners are most interested in reading magazines and newspapers as well as topics related to love, sport and politics. Mothers seem to play a more important role than either fathers or teachers in inculcating reading habits among students. What emerged from this study is that reading is seen as a means to obtain information about topics which perceive as important, but is not seen as a means of independently finding out about their school subjects which suggests that schools might not be encouraging this important aspect of lifelong learning.

According to Croston (2005), he reported that many students enjoy reading popular magazines, horror story, mysterious and other few other topics when they are outside of school. Apart from that, the middle school students also mentioned that they enjoy reading comics. As for the genres of assigned book, it is found that that the students enjoyed both the genres of fiction, and non-fiction but most favourably choose a topic of fantasy, adventure, horror and humour, which indicate to the fiction genres.

Some studies have reported that girls, more than boys, are mostly recommended by family and friends when it comes to selection of books to read as highlighted by Arnstead (2004) who. And again, magazine has been listed as one of the most preferable materials chosen by the students although the topic of interest differs across gender. As for the girls, they enjoy reading magazines about teen issues and pop culture people while the boys read magazines about people of interest to teens and sports magazines. They also reported that Back-of-the-book summaries and series books are primary influences on what they choose to read. Again, family members are named as recommender to what to read.

Another interesting study which has been conducted in a very similar context as the present study who conducted by Annamalai \& Muniandy (2013) have conducted a study which reporting the reading habit and attitudes of the students in a Malaysia Polytechnic. The findings from the study has unravelled that the polytechnics students have low interest in reading and students do not enjoy reading as much as they enjoy engaging themselves in other technology based activity. Apart from these two major conclusions drawn by the researchers, there are few aspects that have been highlighted in relation to the reading materials chosen by the polytechnic students. According to their finding, students generally found to be reading newspapers everyday for at least a few times a week as compared to other reading materials such as magazines, websites, novels, academic books, comic and journals. The indication of high rate of newspapers and magazines have shown that students were found reading entertainment only and not for academic purposes. The study has also concluded that reading is only regarded as a minor activity during leisure time. However, the factors that lead to the scenario have not yet been discovered.

Reports from the findings of previous study have mostly agreed that fiction is the most preferably genres of reading materials chosen by the students regardless on which grades they are in. The Non-fiction books chosen by the students are ranging from fantasy, horror, humour, romance, as well as science fiction. Besides as explained by Arnstead (2004) the students choose a book to read by selecting the next one in a series, another book by the same author, or a book of their favourite type or genre. The students added that 
cover picture and the colours play important aspects on their selection of books by saying that it must be 'attention grabbing'. Other than books, students are reported to mostly read magazines although the topic interest may vary across genders. Girls tend to read teen issues, entertainments as well as fashion as topic interest while boys tend to choose sports and even automotives topics. However, study conducted in polytechnic somehow added newspaper as another material that read by the students. Family members, especially the mother are stated to be the most influential factor to inculcate reading habit towards learner and types of reading materials they choose to read.

Selecting reading materials for reading comprehension in ESL context is acknowledged to be one of the crucial tasks among teachers and educators. Without appropriate reading materials, it will be very difficult for the students to perform better in the classroom. By considering the students' preferences and interests in selecting material, will eventually help to contribute to the students' performance. The findings from the present study could contribute to the literature available in the field of reading in ESL context in which students' preferences towards reading materials becomes the main concern in the study.

\section{METHOD}

The present study is intended to answer two research questions which are (i) What are the students' preferences towards choosing reading materials? and (ii) Why the students choose that materials and what influence them to do the selection?. This study is a qualitative design in nature. In order to find the result for this study, the data was analyzed quantitatively and made reviews on literature from previous researchers. A set of questionnaire are duly adapted from Arnstead (2004) Influences on Students' SelfSelected, Recreational Reading Material and Larsen (1999) A Study of the Reading Interests of HighAbility Readers in a North Carolina Elementary School are used in this study. The questionnaires were distributed to the respondents and analyzed quantitatively. The questions selected are relevant to the present study and exclude the irrelevant. We also added new constructed question based on the necessity in order to answer our research questions. There are two sections in the questionnaire; Section A will cover the demographical background of the participants while Section B will cover the questions of participants' reading interest.

The participants will be selected among the Students of Diploma in Mechanical Engineering and Diploma in Engineering Aircraft Maintenance in Banting Polytechnic. The participants selected are among semester 1 and semester 3 students. The age group is between 19-22 years old and their first language is ranging from Malay, Cantonese, Tamil, Telegu, Bidayuh and Javanese.

\section{FINDINGS AND DISCUSSIONS}

\section{Demographical Background}

Respondents for the case study as mentioned before are from Banting Polytechnic and ranges from first semester and third semester students who are currently taking language as one of the compulsory subject in their course of study. We have come across in many respondents answers in number of years they are learning the language is from 6 years being the minimum an $\mathrm{d} 20$ years of the maximum. The age group we have selected are from 19 - 22 years old and mostly are male as the constraint is found in the student enrolment itself as ratio of male students are higher than the female students. They come from multiple races found in Malaysia who are Malay, Chinese, Indian, Bidayuh and speak multiple first languages such as Malay, Chinese, Tamil, Telegu, Bidayuh and Javanese.

\section{Reading Materials Preferred by Participants}

The table below shows responses to the first three questions in Part B of the survey. The responses to questions 1 "If I had to choose two books to take with me on a long trip into outer space, they would be", question 2 "my favourite author" and question 3 "my favourite books author" are in below tables: 
Table 1: "Q1 - If I had to choose two books to take with me on a long trip into outer space, they would be"

\begin{tabular}{|l|l|l|}
\hline \multicolumn{1}{|c|}{ Books } & \multicolumn{1}{|c|}{ Books } & \multicolumn{1}{c|}{ Books } \\
\hline & \multicolumn{1}{c|}{} \\
\hline •Tun Mahatir & $\bullet$ Novel & $\bullet$ Harry Potter \\
\hline •The Lost world & $\bullet$ Planets of the Apes & $\bullet$ Jakyle \& Hyde \\
\hline •Sherlock Home & $\bullet$ Alice in Wonderland & $\bullet$ Literature \\
\hline •Comic & $\bullet$ Cartoon Books & $\bullet$ Lord of Rings \\
\hline •Magazine & $\bullet$ Travel Books & $\bullet$ The Secret \\
\hline •Airspac & $\bullet$ Pride \& Prejudice & $\bullet$ The Power \\
\hline •Aircraft & $\bullet$ All about Space & $\bullet$ Lawak Kampus' \\
\hline •Ast ronomy & $\bullet$ Planets & $\bullet$ Physic \\
\hline •Galaxy & & \\
\hline •Traffic & & \\
\hline
\end{tabular}

Table 2: “Q2 - My favourite author” \& Table 3 “Q3-My favourite book by this author is...

\begin{tabular}{|l|l|}
\hline \multicolumn{1}{|c|}{ author } & \multicolumn{1}{c|}{ author } \\
\hline William Shakespeare & J K.Rowling \\
\hline Dr.Ferid Murad & NitriqueOxide \\
\hline A.Samad & Lost World \\
\hline Sir Arthur Conan & Harry Potter \\
\hline Sophie Kinsella & Shopaholic \\
\hline & Doyle \\
\hline
\end{tabular}

The first question received a tremendous variety of responses. There were a lot of varieties from biography to science fiction, and novels to comics and even fairy tale stories as clearly shown in Table 1. The students were more towards technical sort of materials reader as they relate better in the studies. For example the list shows planets, astronomy, aircraft, airspace, space survival, galaxy and physics. The science fiction, Space and Harry Potter found as a widespread popularity of series of books selected by the students. Harry Potter is a hit among the students followed by novel without being specific. Pride and Prejudice as well as The Secret were their picks on that genre. Lord of the Rings and Planets of the Apes were also choices chosen by the respondents. Some are seen as an impact on students from the movies they watch in cinemas. Taking about fairy tale titled book "Alice in Wonderland" did look as an odd combination. Not forgetting the students chose thriller too e.g. Sherlock Holmes books and Jekyll \& Hyde. Randomly seen as a choice are the travel books and magazines including a Malay comic/magazine "Lawak Kampus". Biography of Tun Mahathir was also written as one of the book to be taken to outer-space trip. The Power which highlights on success of power within was also stated by respondents. Cartoon books and Literature were reckoned as a choice too.

Question 2 \& 3 didn't fare much in answers with the respondents. It was merely some famous names they quoted and the rest of the author was not highlighted by the respondent. To top it William Shakespeare and J.K Rowling were mentioned followed a rare physician Dr.Ferid Murad as their favourite author. A Local novelist A.Samad and the exciting children novel's author Sir Arthur Conan Doyle was said their favourite authors. A rare find was the name Sophie Kinsella, a British novelist where her book "Shopaholic" where first two Shopaholic books were adapted into a film. And again the question 3 was to find out the books written by the favourite author based from question 2. Many found it difficult to name them and triggered memories of books they had read prior to this survey. 
Table 4: Q4 -The three topics that I most like to read about are:

\begin{tabular}{|l|c|l|c|l|c|}
\hline \multicolumn{1}{|c|}{ Title } & $\begin{array}{c}\text { \# of } \\
\text { responses }\end{array}$ & \multicolumn{1}{|c|}{ Title } & $\begin{array}{c}\text { \#of } \\
\text { responses }\end{array}$ & \multicolumn{1}{|c|}{ Title } & $\begin{array}{c}\text { \#of } \\
\text { responses) }\end{array}$ \\
\hline Sports & 5 & Islamic History & 1 & Business & 1 \\
\hline Humor & 4 & Life & 3 & Facts & 2 \\
\hline Love & 2 & Health & 4 & Moral & 1 \\
\hline Racing & 1 & Financial & 3 & Engine & 1 \\
\hline adventure & 2 & Rare things in the World & 1 & Turbo & 1 \\
\hline Ghost story & 3 & Politics & 4 & Performance & 1 \\
\hline World & 2 & Aviation & 1 & Earth & 1 \\
\hline Artiste & 1 & Life Experiences & 1 & Material & 1 \\
\hline Car & 1 & Parenthood & 1 & $\begin{array}{l}\text { Aircraft } \\
\text { structure }\end{array}$ & 1 \\
\hline Fashion & 2 & Newsfeed & 1 & Engineering & 1 \\
\hline Knowledge & 1 & Cartoon & 1 & Survival & 1 \\
\hline Science & 1 & Fighting & & & \\
\hline Current & 1 & & & & \\
\hline Issues & & & &
\end{tabular}

Table 4 is on the topics where the respondents like to read which shows tremendous variety. They are a widespread of genres and are found in popular books, magazines, journals, web-sites, topping the analysis is, Sports

followed by Health and Humour where 5 - 4 out of the 26 respondents had written them as their preferred genre. Tough to rationalize here, as the students are average readers but yet they mentioned on liking the politics and we found it rather amazing. Ghost story (3) and Financial (3) also were indicated as their favourite reading genres.

Table 5: Friends' and Parents' views of reading (Q10 - Q11)

My parents think reading is;

My friend thinks reading is;

\begin{tabular}{|l|l|l|}
\hline \multicolumn{1}{|c|}{ Answer } & Parents & Friends \\
\hline Very, very important $17(65 \%)$ & $3(12 \%)$ \\
\hline Very Important & $8(31 \%)$ & $5(19 \%)$ \\
\hline Important & $1(4 \%)$ & $14(54 \%)$ \\
\hline Not very Important & & $3(12 \%)$ \\
\hline Not important at all & & $1(4 \%)$ \\
\hline
\end{tabular}

The respondents seem to have a direct difference on the parents' and friends' views of the importance of reading. Mostly found parents' of theirs have a serious say on reading. The parents are constantly showing warning to these students on reading being "very, very important" $(65 \%)$ and "very important" (35\%). For friends, the opposite was true. 14 out $26(54 \%)$ respondents' viewpoint was reading is"Important", while $3(12 \%)$ said it is "not very important" and $1(4 \%)$ said "not important at all". All the respondents who are students are felt that parents valued reading and their influence plays an important role in the development of their children's reading ability. Parents are motivators, where they encourage reading activities and offer their children more opportunities to read. The friends of the respondents however have an opposite influence. They do not regard reading as highly workable activity. While parents are encouraging the reading as a great guide and influence, friends hinder and are a block to these 
respondents. They do not seem to very much share the same interest with friends. Peers deter and feel reading to be of little or no importance which may stop the respondent from reading further.

Table 6: Sources for reading material (Q12, Q16-Q20)

\begin{tabular}{|l|c|c|c|c|c|c|}
\hline $\begin{array}{c}\text { Answer / } \\
\text { Frequency in } \\
\text { Numbers }\end{array}$ & $\begin{array}{c}\text { Public } \\
\text { Library }\end{array}$ & $\begin{array}{c}\text { School } \\
\text { Library }\end{array}$ & Home & Classroom & Bookstore & $\begin{array}{c}\text { Friends' } \\
\text { books }\end{array}$ \\
\hline Most of the time & & 4 & 1 & 2 & 2 & 4 \\
\hline Often & 7 & 6 & 6 & 5 & 4 & 5 \\
\hline Sometimes & 19 & 13 & 11 & 14 & 8 & 12 \\
\hline $\begin{array}{l}\text { Not very } \\
\text { Often }\end{array}$ & 3 & 7 & 3 & 10 & 4 \\
\hline Almost Never & & & 1 & 2 & 2 & 1 \\
\hline
\end{tabular}

School Library (4 out of 26) and friends' books (4 out of 26) were found as one of the most sort out sources to find reading material. These students were finding for sources which are readily available as school library and friends where books are easily accessed to find for information for their language classes. Not forgetting public library, where 7 out 26 respondents said often they use it. Home and bookstore which are rated by 10 out of 26 respondents and 7 out of 26 respondents respectively was 'not very often' looked out for to find resources. Many of these students are staying away from parent and are on their own that explains why 'Home' not very often found an easy access. That directly indicates the reason of choosing bookstore the 'not very often' source due to financial situation. The respondents have to rely on their study loan and parents minimal financial support to sustain in the campus. So that hinders from respondent to go to bookstore or even spend their money there.

Table 7: Source of Reading material (Q13 - Q15)

\begin{tabular}{|l|c|c|}
\hline \multicolumn{1}{|c|}{ Books } & Yes & No \\
\hline Certain kind & 22 & 4 \\
\hline Certain author & 8 & 18 \\
\hline Certain series & 11 & 15 \\
\hline
\end{tabular}

The finding shows $85 \%$ of the respondents said they choose only certain kind of reading materials which were 22 out of 26 respondents. Mostly answered 'No' to choosing the author before their selection of reading material. $57 \%$ respondents felt that they do not pick books according to certain series. This may be due to that the language learning classroom has variety of exercises which defers the topic based on syllabus so any continuous series selection not much favoured here.

Table 8: Favourite kind of books to read (Q22)

\begin{tabular}{|l|l|}
\hline Fantasy & 1 \\
\hline Humor & 2 \\
\hline Mystery & 3 \\
\hline Information Books & 4 \\
\hline Contemporary Fiction & 5 \\
\hline Biography 6 & 6 \\
\hline
\end{tabular}




\begin{tabular}{|l|l|}
\hline Science Ficton & 7 \\
\hline Poetry & 8 \\
\hline
\end{tabular}

Somehow or rather the students like to invade fantasy world. Age and their environment in knowing engineering fact are perceived as an influence to read such books. Nevertheless, having chosen 'Humor' books makes the respondent to read for pleasure. Mystery is shown next to Humor then followed by Information books, Contemporary fiction, Biography, Science Fiction and Poetry.

Table 9: Favourite kind of things to read (Q23)

\begin{tabular}{|l|l|l|l|}
\hline Comic books & 1 & Newspaper & 5 \\
\hline Software and computer games & 2 & Novel & 6 \\
\hline Web pages & 3 & Encyclopedia & 7 \\
\hline Magazine & 4 & Picture Books & 8 \\
\hline
\end{tabular}

The respondents have chosen to be light and easy as well as to fit their interest - comic topped the choice. It matches, Day and Bamford, (2002) whom quoted Ray Williams's (1986), the third principle out of the top ten principles that learners choose what they want to read. Software \& computer games and web pages to keep on top of market surroundings. Their choice of things they read were found informal and based on interest more. Web reading is popular but diversion towards other content online can also happen here. (Games or 'unhealthy site etc.)

Table 10: Methods of Selection (Q24)

\begin{tabular}{|l|c|c|c|}
\hline \multicolumn{1}{|c|}{ Methods } & First (\#)f & Second (\#)f & Third (\#)f \\
\cline { 2 - 4 } & responses) & responses) & responses) \\
\hline Having the books assigned in class & 6 & 2 & 2 \\
\hline Hearing about the book from a friend & 5 & 2 & 1 \\
\hline $\begin{array}{l}\text { Hearing about the book from a librarian } \\
\text { Hearing about the book from a parent }\end{array}$ & 1 & 1 & 2 \\
\hline Hearing about the book from a teacher & 4 & 3 & 1 \\
\hline Surveying from the internet & 6 & 5 & 1 \\
\hline $\begin{array}{l}\text { Booking through bookshelves for books } \\
\text { that seem }\end{array}$ & 2 & 5 & 1 \\
\hline $\begin{array}{l}\text { interesting } \\
\text { Receiving the book as a gift }\end{array}$ & 1 & 4 & 5 \\
\hline $\begin{array}{l}\text { Searching for books on a particular subject } \\
\text { Seeing a movie or TV show based on the } \\
\text { book }\end{array}$ & 1 & 2 & 5 \\
\hline
\end{tabular}

Findings show the pick being for respondents were having the books assigned in class, surveying from the web page, hearing from friend, hearing from teacher is most sort out. Not any of them wants to hear from the librarian. These answers suggest that the readers here like to seek books out on their own. The popularity of receiving books as a gift is found rather surprising. Students may find sentiment involved in one giving a book as a gift and carry great meaning for the students. They then read the book showing fondness for the giver. Also when it's given as a gift it is

available right in front of them. So they read the book. Point to be taken here if we can encourage or instill 
reading in students we can use 'gift' as a tool of motivator.

Another factor is 'hearing from friend' which is second most favored. Sense of believability and trust in friends could be the main reason for such choice. Despite the fact, the previous question said that friends were not the influence in choosing the reading material, peer recommendation of books still seem to carry a great deal of weight in students. They seem to share the trend and culture of students to gather knowledge. One may read what friends are reading and buy the same books where friends buying. So it is again peer pressure or peer recommendation could be working for these respondents.

Educator/teacher is also seen as motivator here. Responses say that teacher guiding them to choose a book is very much followed rather than asking a librarian or even looking for it at the bookshelves or bookstores. As teachers have direct contact with language learning classroom the respondents feel the importance after friends to choose the books suggested by teachers to enhance knowledge and information.

Table 11: Influence on the Choice of Reading Materials (Q25)

\begin{tabular}{|l|c|c|c|}
\hline \multicolumn{1}{|c|}{ Methods } & First (\#) & Second (\#) & Third (\#) \\
\hline Easy to Access & responses) & responses) & responses) \\
\hline Easy to read (comprehension) & 12 & 1 & \\
\hline Relevant to course studies & 3 & 6 & 1 \\
\hline Font type & 2 & 3 & 6 \\
\hline $\begin{array}{l}\text { Graphically shown text/materials } \\
\text { Others (specify) }\end{array}$ & 1 & 1 & 1 \\
\hline
\end{tabular}

Findings which highlights on the "influence on the choice of reading materials" shows that respondents choose items which are easy to read followed by easy to be looked for or accessed. Choosing is not done based on 'relevant to course studies' as the students feel that anything which is easily understood and easily found could be of great help to their studies. Font type and graphically shown materials are not found as influence to their material choosing.

Table 12 Influence on the Choice of finding materials for coursework (Q26)

\begin{tabular}{|l|c|c|c|}
\hline \multirow{2}{*}{ Methods } & First (\#)f & Second (\#of & Third (\#)f \\
\cline { 2 - 4 } & responses) & responses) & responses) \\
\hline Newspaper & 10 & 2 & 3 \\
\hline Course book & 6 & 4 & 5 \\
\hline Magazines & 3 & 6 & 3 \\
\hline Fictions & 2 & 1 & 1 \\
\hline Non-fictions & 1 & 3 & 1 \\
\hline Lecture Notes & 1 & 3 & 5 \\
\hline $\begin{array}{l}\text { Web pages on Internet } \\
\text { Others (specify) }\end{array}$ & & 3 & \\
\hline
\end{tabular}

Respondents have a simple way of looking for reading materials for their task in language classroom. Newspapers were relied upon most followed by course book. Magazines are included with fictions which are made useful for their task completion. Surprisingly many do not use the lecturer's notes and web pages on the internet were seen only being the third option for them. Again probably, the students were having difficulties with the lecturers' instructions to seek information in the web pages in the internet. The purpose of reading is usually related to pleasure, information and general understanding. (Day \& Bamford, 2002). It is found to be the choice and the understanding to complete task which made students respond 
as in above table.

Table 13: Influence On Choices Of Reading Materials (Q8)

\begin{tabular}{|c|c|c|c|}
\hline \multicolumn{5}{|c|}{ Influences } \\
\hline Title & Course based & Facts & True stories \\
\hline Cover page & Current issue & Story & Information \\
\hline Racing & Favourites & Adventure & \\
\hline
\end{tabular}

The above show the influence on choice of reading materials. They were highlighted randomly not in correct order. Then again these are all the items which influence them before choosing material to read. Ranging from title, course based, cover page, current issue, racing, facts, true story, stories, information and adventure based. Annamalai \& Muniandy (2013) quoted one choose materials which are "attention grabber" and not something which is a put off for students.

From Question12 in the questionnaire, we can see the students have listed on the "best thing that teachers/lecturers can do to encourage students to read" a wide range of popular solutions such as; library hunting, competitions, participation in forums, competitions, organize play \& drama, read together, give story books and assignment or even simple reading material to bring the interest and motivate the students. Teachers can explain that reading extensively leads not only to gains in reading proficiency but also to overall gains in language learning. Teachers can reassure students that a general, less than $100 \%$, understanding of what they read is appropriate for most reading purposes by guiding through what is relevant for their course of study. Students here maybe responding well and better with a guide as well as solution to make them read in English, to have the knowledge as well as wisdom to converse and apply the language effectively.

\section{CONCLUSION}

The overall findings from the present study has resembled the findings elicited by Annamalai \& Muniandy (2013) which said that polytechnic students have low of interest in reading and students do not enjoy reading as much as they enjoy themselves engaging in other technology based activity. The findings also show that parents seem to be the most influential factor in students' reading habit, parallel to what is reported by Nomakhosazana (2002), found mothers seem to play a more important role than either fathers or teachers in inculcating reading habits among students. Next, in terms of the materials of reading, the students were found reading for mostly for entertainment and not for academic purposes similarly to what had been reported by Annamalai \& Muniandy (2013). The findings also suggest that students want to have easy reading materials only in a sense that it is easy to comprehend as well as easy accessibility. The resources are mainly found in the library, friend's recommendation followed by bookstore and classroom. The participants are mainly chosen the fictional genre of reading which they read for pleasure even though the topic interests are vary. Yet, they mainly read newspapers, course book in completion of their assignments and coursework.

\section{REFERENCES}

Annamalai, S., Muniandy, B. 2013. Reading Habit and Attitude Among Malaysian Polytechnic Students.International Online Journal of Educational Sciences. 5(1), 32-41.

Arnstead, C. B., 2004. Influences On Students' Self-Selected, Recreational Reading Material. Available at http://dianedalenberg.files.wordpress.com/2012/05/infl-on-stud-self-selec-rec-rdg-mat-lit-reviw.pdf 
Ashley, W. L., 1999. A Study Of The Reading Interests Of High-Ability Readers In A North Carolina Elementary School. Available at http://ils.unc.edu/MSpapers/2492.pdf

Croston, B., 2005. An Investigation Of The Relational Between Student Reading Interest And Teacher Selected Novels. Available at http://etd.ohiolink.edu/view.cgi7acc num=bgsu1122664868

Harison, M. S., 2010. An Analysis Of The EFL Secondary Reading Curriculum In Malaysia: Approaches To Reading And Preparation For Higher Education. Available at

http://d- scholarship.pitt.edu/9837/1/mohdsidekharison2010.pdf

Nomakhosazana, H. R., 2002. The Reading Preferences Of Grade 11 ESL Learners In Grahamstown. Available at http://eprints.ru.ac.za/2370/ 